\title{
RURAL-TO-URBAN MIGRATION AND REALIZATION OF EXPECTED BETTER LIFE IN BANGLADESH: AN EMPIRICAL STUDY IN RAJSHAHI CITY CORPORATION
}

\author{
Samira Salam ${ }^{1+}$ \\ Md. Abul Kalam \\ Azad $^{2}$ \\ (iD) Md. Abdus Salam ${ }^{3}$ \\ Mohammad M. \\ Islam $^{4}$
}

\author{
${ }^{\prime}$ Department of Basic Science, Primeasia University, Banani, Dhaka, \\ Bangladesh. \\ Email:fatima.al-qeyam@iu.edu.jo Tel:880-1778657341 \\ ${ }^{2}$ Government BL College, Khulna, Bangladesh. \\ ${ }^{3}$ Department of Statistics, Jahangirnagar University, Savar, Dhaka, \\ Bangladesh. \\ ${ }^{4}$ Department of Mathematics, Utah Valley University, Orem, USA.
}

(D) Check for updates

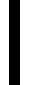

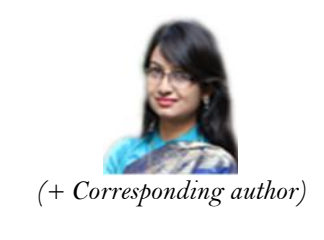

Article History

Received: 3 August 2020

Revised: 16 September 2020

Accepted: 28 September 2020

Published: 8 October 2020

Keywords

Rural-urban migration Expectation of better life

Realization of expected life Standard of living

Logistic regression analysis.

\section{ABSTRACT}

Rural-urban migration is a natural process by which migrants migrate from less developed places of origin to more developed destinations in search of a better quality of life. The main objective of this study is to evaluate the realization of an expected better life and to recognize the determinants that are considered helpful in achieving a better life for migrants in Bangladesh that contribute significantly. A cross-sectional sample survey was conducted on the households of the migrants selected using a threestage cluster sampling technique to obtain the information necessary for the study. The results suggest that it was the pull factors that motivated more than two-thirds of migrants to move from rural to urban areas. Nearly 95 per cent of migrants migrated to destination areas in search of a better life. Realizing a better quality of life was associated statistically significantly with income, occupation, educational qualification, accessibility to health care services, transportation system, and housing facilities in the places of destination. The logistic regression analysis showed that the realization of a better life was more in migrants engaged in service, who belonged to the higher-income groups (more than BDT 15000 per month), who had easy access to specialist health care physicians/hospitals, and who lived close to supportive, highly committed to social welfare, and disciplined neighbors. So, a desirable combination of these supporting components may help migrants achieve their better life goals.
\end{abstract}

Contribution/ Originality: This study contributes to existing literature by understanding the extent to which expected better lives of migrants due to migration are realized. The study findings will assist migrants to recognize the determinants that can lead to achieving the desired better life through migration.

\section{INTRODUCTION}

Migration is one of the three principal components of demography (birth, death, and migration). It is defined as the geographic movement of people across a defined boundary to set up a new permanent or semi-permanent residence. Migrants typically migrate from less developed places of origin to more developed destinations, with the hope of a better life (Akther \& Bauer, 2014; Ma, Chen, Che, \& Fang, 2019; Nahar, 2020). Rural-urban migration is an important indicator of regional disparity in terms of economy, housing, employment, living standards, and 
opportunities for health and education (Hakim \& Boz, 2019; Istiaque \& Mahmud, 2011; Wang \& Fu, 2019; Young, 2013). This inequality could be explained by the large observed productivity and wage gaps between rural and urban workers (Gollin, Lagkos, \& Waugh, 2014; Young, 2013). In an economically developing country this type of inequality is a common feature. This inequality results from the overwhelming concentration of assets, wealth, economic activities, purchasing capacity, and variety of services in urban areas as well as continued abandonment and degradation of rural environments (Akther \& Bauer, 2014; Ma et al., 2019). Thus, rural people migrate to urban areas to look for perceived or actual opportunities in urban centers created as a result of wealth disparity between rural and urban areas (Madu, 2006; Young, 2013).

A country's economic development can be realized as a process of shifting that country's economy from traditional agricultural society to an economy in which both production and employment share of agriculture is declining while industry and service sectors are rising (Mulubrhan, Lena, \& Hermann, 2011). This process is driven by economic forces in the trail of decreasing income elasticity of agricultural goods as income per capita increases. The migration of rural people out of agriculture to find better jobs in urban areas has thus become a natural process in developing countries (Biswas, Kabir, \& Khan, 2019; Rashid, 2013; Young, 2013). Microeconomic models of migration thus treated migration as an investment in human capital (Sjaastad, 1962; Todaro \& Maruszko, 1987). Migration 's economic gain aspect is the expected wage difference and migration's non-market benefits are greater access to health, education, and residential facilities.

Like many other developing countries, the rural-urban migration rate in Bangladesh is rising significantly (Biswas et al., 2019). The urban population as a percentage of the total population increased from about 8 percent to about 23 percent during the periods 1974-2001 (Rashid, 2013) and in 2018 to about 36.6 percent (World Bank, 2007). The most significant factor for urbanization in Bangladesh is rural-urban migration (Istiaque \& Mahmud, 2011; Rashid, 2013; Uddin \& Firoj, 2013). Rapid urbanization will render cities with high levels of congestion and pollution, slum development, crime, social problems, and the growth of a largely uncontrollable informal sector of employment, and these are the traditional externalities of immigration (Adams, Islam, \& Ahmed, 2015; Biswas et al., 2019; Uddin \& Firoj, 2013).

Globally, the relationship between migration and development has been a debatable issue (Adams, 2006; Hakim \& Boz, 2019). Hence the process of moving people to other places in search of a better life is not a novel one. Ruralto-urban migrants expect better lives in terms of jobs, housing, education and health (Biswas et al., 2019; Hakim \& Boz, 2019; Katewongsa, 2015). But not all decisions on migration are correct to meet the desired degree of better life. Many migrants end up in uncertain and dangerous occupations and often have to work in unsafe environments with terrible hygienic conditions. It is therefore important to understand what has been achieved by growing migration in the quest for a better quality of life by low-skilled and low-wage workers, as well as high-skill and high-wage workers from less developed areas of origin to more developed areas of destination. This study focused on understanding the realization of a better life expected as a result of rural-urban migration in search of perceived or real opportunities in the destination places.

\section{METHODOLOGY}

The research was carried out at Rajshahi City Corporation in Bangladesh. Rajshahi City Corporation, situated on the north bank of the Padma River, near the border between Bangladesh and India, with a population of over $3,88,811$ people, is a metropolitan city, one of the Bangladesh's main urban, commercial and educational center. The target population for the study was the migrants who came to the city in search of a better life from Bangladesh's rural areas. At the first stage, one out of 12 city corporations was randomly selected with a three-stage cluster sampling technique. Rajshahi City Corporation, selected at first stage, has 35 administrative units called "Ward," three of which were randomly selected at second stage. Every Ward is divided again into the smallest unit called "Mohalla." At the third stage, one Mohalla was randomly selected from each selected Ward. With face-to-face 
interviews and a structured questionnaire, all the households of migrants from the selected Wards were surveyed for data collection. In total, 480 migrants' households were identified using snowball sampling technique. The data were analyzed by using IBM SPSS Statistics 23 software.

\section{RESULTS AND DISCUSSION}

\subsection{Urban and Rural Population Growth Scenario in Bangladesh}

Figure 1 represents the growth of urban and rural population in Bangladesh during the period 1960-2018. From the figure it is observed that Bangladesh's urban population growth was always higher than the rural population growth. The growth of the urban population during the period 1960-1990 was above 4 percent and during 1991-2018 was above 3 percent. On the other hand, rural population growth has been steadily declining and less than 2 percent in 1988-2018, reaching nearly 0 after 2008, and becoming negative since 2014. Urban population growth takes place through three interrelated processes: (1) rural to urban migration, (2) natural increase, and (3) reclassification. Rural-urban migration contributes directly to the change of the urban population in a country A natural increase in rural populations indirectly changes urban growth by pushing rural people into urban areas as a means of reducing overpopulation compared to economic opportunities available in rural areas. Meanwhile, with the relatively young age structure that characterizes urban populations, the rate of natural increase has a direct effect on urban population growth. Reclassification is an administrative process through which, when the absolute population size or population density exceeds that threshold, urban status is granted on an earlier rural or peri-urban territory based on a certain threshold.

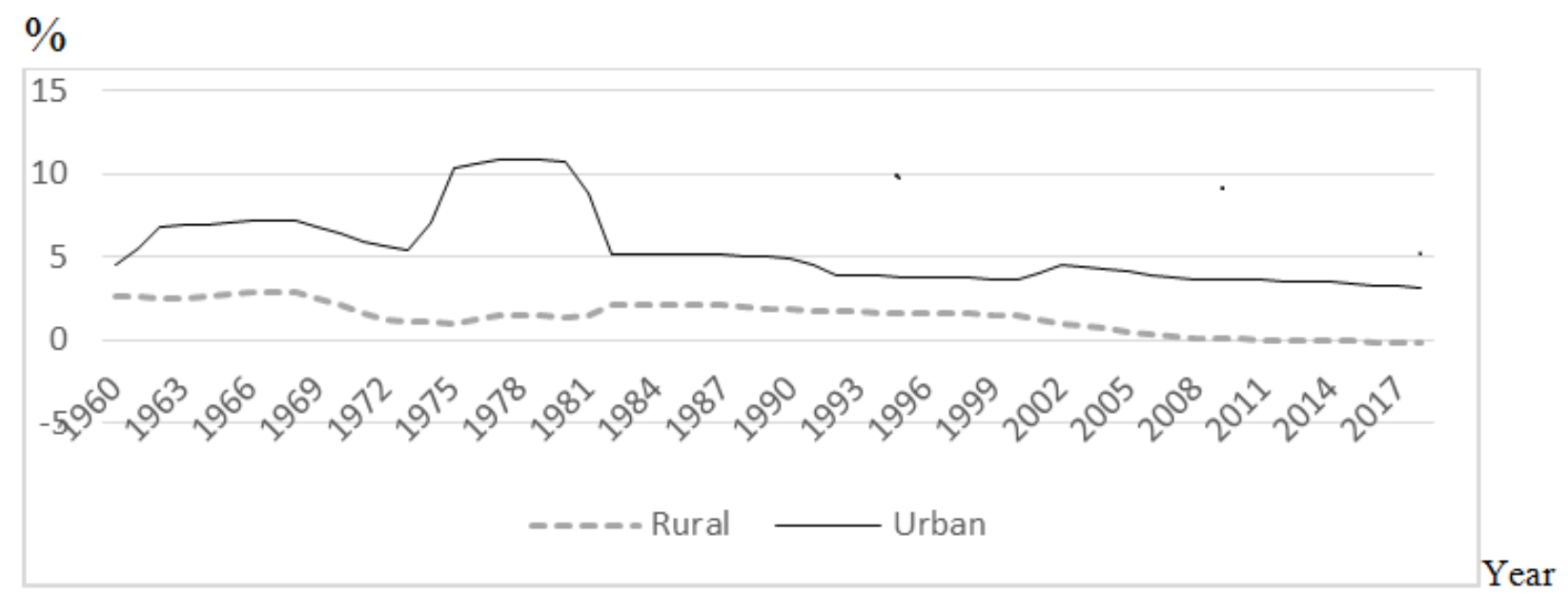

Figure-1. Urban and rural growth rate in Bangladesh.

\subsection{Background Profiles of the Migrants}

The descriptive statistics provide some detail about the migrants' reasons for migration and living and working conditions, both at the place of origin and at the place of destination. Demographic characteristics, socioeconomic status, and personality traits make some people more likely to migrate than others (Guest, 2003; Nauman, Van Landingham, Anglewicz, Patthavanit, \& Punpuing, 2015). Approximately 7 percent of migrants were under 30 years of age, about 31.5 percent were 40 49 years of age group, and about 16.3 percent were 60 years of age and older Table 1. The respondents' mean age was 45.2 years, with standard deviation (S.D.) 12.2 years. About 32.2 percent of migrants had less than 10 years of schooling, about 33.3 percent were Masters (17 + years of schooling), and about 20.2 percent were Bachelor's. The migrants' average schooling years was 12 school years with S.D. 5.7 years education. From the results it is evident that a significant proportion of migrants have been educated higher. In rural areas, there are no or few options for suitable employment for higher educated people. Agriculture and small business are the most common employment available in rural areas. Higher educated people are not interested 
in taking up farming or small business as their profession. Equivalent work opportunities vary between rural and urban areas. Discrepancies in total productivity factor are responsible for differences across countries in equal work opportunities and per capita income. Studies have found that misallocation of production factors within an economy across regions can cause these differences in overall productivity (Hsieh \& Klenow, 2009; Restuccia \& Rogerson, 2008). An uneconomical distribution of workers across regions is the most significant cause of misallocation (Bryan \& Morten, 2015; McMillan \& Rodrik, 2011; Restuccia, Yang, \& Zhu, 2008; Vollrath, 2009). Thus, people with higher education and skills have a greater tendency to move to urban areas to look for perceived or actual desirable job opportunities. Fortunately, moving rural people out of agriculture to find employment in urban areas is a major ingredient in the development process, particularly in developing market economies (Niva, Taka, \& Varis, 2019; Young, 2013). This is illustrated by the broad productivity and wage differences identified among rural and urban workers (Gollin et al., 2014; Young, 2013). With regard to the type of occupation, about 52.9 percent of migrants were in service, about 22.9 percent were in business, about 11 percent were day laborers and the remaining 13 percent were in unclassified employment. The study results indicate that according to their expectations a significant proportion of migrants could be involved in the development process. About 96.5 percent of the migrants were married and about 91.7 percent were male. One measure of a migrant 's general living conditions is the home or dwelling status of the migrant. Most migrants lived in rented dwellings (about 52.2 per cent), dwelled in their own apartments (about 26.9 per cent), and about 20.9 per cent inhabited in slums.

Table-1. Background profile of the respondents.

\begin{tabular}{|c|c|}
\hline Characteristics & Percent \\
\hline \multicolumn{2}{|c|}{ Age (in years) } \\
\hline$<30$ & 7.1 \\
\hline 30-39 & 24.6 \\
\hline $40 \sim 49$ & 31.5 \\
\hline $50 \sim 59$ & 20.6 \\
\hline $60+$ & 16.3 \\
\hline Mean $\pm S D$ & $45.2 \pm 12.2$ \\
\hline \multicolumn{2}{|c|}{ Education (in schooling years) } \\
\hline$<10$ & 32.2 \\
\hline $10-12$ & 14.2 \\
\hline $13-16$ & 20.2 \\
\hline $17+$ & 33.3 \\
\hline Mean ISD & $12.0 \pm 5.7$ \\
\hline \multicolumn{2}{|c|}{ Present occupation } \\
\hline Service & 52.9 \\
\hline Business & 22.9 \\
\hline Day labor & 11.1 \\
\hline Others & 13.1 \\
\hline \multicolumn{2}{|c|}{ Marital Status } \\
\hline Married & 96.5 \\
\hline Others & 3.5 \\
\hline \multicolumn{2}{|c|}{ Sex } \\
\hline Male & 91.7 \\
\hline Female & 8.3 \\
\hline \multicolumn{2}{|c|}{ Residence type in the place of destination } \\
\hline Slum & 20.9 \\
\hline Rented house & 52.2 \\
\hline Own house & 26.9 \\
\hline
\end{tabular}




\subsection{Migration Characteristics}

Table 2 details the key features of the migration process. The reasons for migration of people, some of whom are closely linked to the economic situations in their places of origin, affect their everyday lives. The reasons manifest themselves in the migrants' fears about income generation for everyday life in the places of origin and in their aspirations of a better life in the places of the destination. The realization of a better life expected is better understood if the expectation of a better life and the reasons for the migration has matched one another. Thus, to understand whether migrants' expectation of a better life is realized or not, it is important to identify the reasons for their migration. The dominant factors of migration (about 66.6 percent of cases) are obviously pull factors. Because of large job and wage gaps between rural and urban workers, urban centers are the right places for people who want to fulfill their expectations of a better life. Low adaptive capacity across the place of origin generally pushes people to migrate to the destination. On the other hand, factors such as perceived or real opportunities for suitable jobs, children's education facilities, improved health care facilities pull migrants into urban areas to settle in. According to the study results, about 62.7 percent of the migrants settled in the Rajshahi city permanently because they could realize their expectations. Approximately 39.4\% of migrants migrated from neighboring areas (a distance of less than $50 \mathrm{~km}$ ), approximately $21.7 \%$ came from a distance of $50 \sim 99 \mathrm{~km}$ from Rajshahi City, and $17.3 \%$ of migrants came from more than $200 \mathrm{~km}$ from their places of origin. The mean distance between place of origin and destination was $119 \mathrm{~km}$. Approximately 28 percent of respondents migrated less than 5 years ago to Rajshahi City, about 20.4 percent migrated 5 9 years ago and 23.8 percent migrated 20 years ago or more. The average migrated life duration in the destination places was 14 years.

Table-2. Characteristics of migration process.

\begin{tabular}{c|c}
\hline \multicolumn{1}{c}{ Characteristics of migration } & Percent \\
\hline Causes of migration & 66.6 \\
\hline Pull factors & 33.4 \\
\hline Push factors & 62.7 \\
\hline Permanent & 37.3 \\
\hline Temporary & \\
\hline Distance (in km) from place of origin \\
\hline$<50$ & 39.4 \\
\hline $50 \sim 99$ & 21.7 \\
\hline $100 \sim 149$ & 13.8 \\
\hline $150 \sim 199$ & 7.9 \\
\hline $200+$ & 17.3 \\
\hline Mean \pm SD & $119 \pm 121$ \\
\hline Duration of living in current place $($ in years $)$ \\
\hline$<5$ & $14.0 \pm 10.5$ \\
\hline $5 \sim 9$ & 28.1 \\
\hline $10 \sim 14$ & 20.4 \\
\hline $15 \sim 19$ & 15.0 \\
\hline $20+$ & 12.7 \\
\hline Mean \pm SD & 23.8 \\
\hline
\end{tabular}

\subsection{Remittance}

One of the outcomes of rural-to-urban migration is the migrants' income generation and transfer to their respective place of origin. Several authors have recently argued that migration is a typical process of the modern economy and has a significant impact on rural economic development, in particular in removing supply constraints to improve agricultural productivity (Rempel \& Lobdell, 2007; Stratana \& Chistrugaa, 2012). In the process of transformation, migration acts as a catalyst not only for the destiny of individual migrants but also for the conditions of the family members left behind, local communities and the broader sending regions (Nguyen, Grote, \& 
Nguyen, 2019; Phan \& Coxhead, 2019). Migration has been identified as a strategy of survival mainly used by poor rural dwellers. Most people left by migrants are always awaiting remittances from the migrants. Households receiving these remittances tend to use earnings primarily for current consumption (food, clothing), as well as investments in education for children, health care, improvement in household food and security, and water and sanitation (Acharya \& Leon-Gonzalez, 2014; Meyer \& Shera, 2017; Nguyen, Grote, \& Nguyen, 2017). The importance of transferring remittances is that it helps those left in rural areas to survive in hardships associated with a decrease and/or complete depletion of the environmental resources on which their livelihood depends. The results in Table 3 show that about 77.7 percent of migrants send less than BDT 1000 as remittances to rural households and only 7.9 percent of migrants send BDT 3000 or more to rural households as remittances. Despite the amount of remittance transfers appear to be too small, a steady supply of remittances is viewed with utmost importance in increasing their farm earnings and other livelihood sources.

Table-3. Remittance per month

\begin{tabular}{c|c}
\hline Amount of remittance per month & Percent \\
\hline <BDT 1000 & 77.7 \\
\hline BDT $1000 \sim 1999$ & 11.9 \\
\hline BDT $2000 \sim 2999$ & 2.5 \\
\hline BDT 3000 & 7.9 \\
\hline
\end{tabular}

\subsection{Expectations of Better Life and Realization of Expectations}

The aspirations of Migrant for a better life and his / her motivation to seek higher earnings along with other incentives have boosted rural people's movement to urban areas. But not all decisions on migration are capable of bringing expected success. Migrants sometimes end up in bad and dangerous jobs including prostitution and child labor. Policymakers tend to accept these negative externalities as an unavoidable by-product of development, believing that being "poor in the city" is still better than being "poor in the village" (Amare, Hohfeld, Jitsuchon, \& Waibel, 2012). The intention of rural-urban migration in the study area was obviously dominated by expectations of a better life. Approximately 95.6 percent of the key aspiration of migrants was to have a better life. Table 4 shows that about 88.6 percent of migrants believed their expectations of a better life had been met through migration. Approximately 91.6 percent of migrants realized that their living standards had improved as a result of migration.

Table-4. Percent distribution of migrants regarding expectation of better life.

\begin{tabular}{l|c}
\hline Regarding expectation of better life & Percent \\
\hline Expected better life & 95.6 \\
\hline Fulfilled expectation & 88.6 \\
\hline Improved standard of living & 91.6 \\
\hline
\end{tabular}

\subsection{Association of Improved Living Standards and Socioeconomic Conditions}

Migrants left their place of origin in search of a better life at the destination places. The expectations of migrants originated mainly from the hope that migration might lead to an improved standard of living. Improving a standard of living may depend on certain socioeconomic factors. An association between the improvement status of a migrants' standard of living and their socioeconomic conditions has been empirically demonstrated in this study, and is presented in Table 5. Migrants whose incomes were higher could, quite naturally, significantly improve their living standards more than migrants whose incomes were lower. With respect to employment, migrants engaged in business and service could significantly improve their living standards more than migrants whose occupations were not business and service. As for the level of education, migrants whose education levels were higher could significantly improve their living standards against low-educated migrants. One of the key components for improving the standard of living is the availability of health facilities. Study results indicate that easy accessibility of health care facilities such as specialized physicians, specialized hospitals, reliable diagnostic 
centers and trustworthy treatment are significantly associated with improving living standards. The transport system of the destination's place is also associated significantly with the improvement of living standards. Migrants felt that their standard of living had been significantly improved by the urban areas' transport system without traffic jams, environmentally friendly and safe. Housing was also associated significantly with the increase of living standards. Migrants who stayed in their own apartments and the rental apartment could raise their living conditions significantly.

Table-5. Influencing factors for realization of expectation of better life.

\begin{tabular}{|c|c|c|c|c|}
\hline \multirow[t]{2}{*}{ Factors } & \multicolumn{2}{|c|}{ Standard of living } & \multirow{2}{*}{$\chi^{2}$} & \multirow[t]{2}{*}{ p-value } \\
\hline & Improved & Did not improve & & \\
\hline \multicolumn{3}{|c|}{ Income (in BDT) } & 42.42 & 0.001 \\
\hline$<5000$ & 73.4 & 26.6 & & \\
\hline $5000 \sim 15000$ & 93.0 & 7.0 & & \\
\hline $15001 \sim 30000$ & 97.6 & 2.4 & & \\
\hline $30000+$ & 97.0 & 3.0 & & \\
\hline \multicolumn{3}{|c|}{ Occupation } & 35.21 & 0.001 \\
\hline Business & 92.7 & 7.3 & & \\
\hline Day labor & 70.9 & 29.1 & & \\
\hline Service & 96.4 & 3.6 & & \\
\hline Others & 88.9 & 11.1 & & \\
\hline \multicolumn{3}{|c|}{ Educational qualification } & 36.20 & 0.002 \\
\hline Illiterate & 71.1 & 28.9 & & \\
\hline Primary & 85.7 & 14.3 & & \\
\hline Secondary & 87.5 & 12.5 & & \\
\hline $\mathrm{SSC}$ & 91.7 & 8.3 & & \\
\hline $\mathrm{HSC}$ & 92.6 & 13.1 & & \\
\hline Undergraduate \& above & 96.8 & 3.2 & & \\
\hline \multicolumn{3}{|c|}{ Attitude of law enforcing agencies } & 5.84 & 0.210 \\
\hline Neutral & 92.8 & 7.2 & & \\
\hline Honest & 86.5 & 13.5 & & \\
\hline Supportive & 95.0 & 5.0 & & \\
\hline Coordinated & 90.4 & 9.6 & & \\
\hline \multicolumn{3}{|c|}{ Availability of health facilities } & 8.87 & 0.05 \\
\hline Available specialized doctors & 93.7 & 6.3 & & \\
\hline Available specialized hospital & 92.0 & 8.0 & & \\
\hline Reliable diagnosis lab & 100.0 & 0.0 & & \\
\hline Trustworthy treatment & 88.9 & 11.1 & & \\
\hline Others & 71.4 & 28.6 & & \\
\hline \multicolumn{3}{|c|}{ Transport system } & 13.71 & 0.001 \\
\hline Without traffic jam & 100.0 & 0.0 & & \\
\hline Cheap & 88.6 & 11.4 & & \\
\hline Environmentally friendly & 95.3 & 4.7 & & \\
\hline Safe & 90.9 & 9.1 & & \\
\hline \multicolumn{3}{|c|}{ Housing } & 17.20 & 0.002 \\
\hline Own house & 93.1 & 6.9 & & \\
\hline Rented house & 100.0 & 0.0 & & \\
\hline Slum & 81.0 & 19.0 & & \\
\hline Others & 83.3 & 17.7 & & \\
\hline
\end{tabular}

\subsection{Logistic Model}

Realization of an expected better life due to rural-urban migration is a random-choice problem. Two choices were designed for the problem in the questionnaire, namely, realized an expected better life $=1$, did not realize a better life expected $=0$. Thus, the stated variable was the realization of a better existence expected, which belongs to a variable of $0-1$. For each subject reporting the realization of an anticipated better life due to rural-urban 
migration $(\mathrm{Y}=1)$, the logistic model was fit to the dichotomous outcomes denoted by $\mathrm{Y}$. This model is a discrete binary model of choice that uses logical distribution as the distribution of probability of random error terms. It is ideal for evaluating the realization of an anticipated better life based on the concept of realization of the maximization of a desired better life. The independent variables $\mathrm{X}$ in the model are the variables which could affect the realization of a better life expected of migrants. Suppose that $\mathrm{f}(\mathrm{x})=\beta_{0}+\beta_{1} \mathrm{X}_{1}+\beta_{2} \mathrm{X}_{2}+\ldots+\beta_{n} \mathrm{X}_{\mathrm{n}}$ is a linear function for variables influencing realization of migrants' expected better life, then the probability that migrants' realization of an expected better life due to rural-urban migration $P_{i}=e^{f(x)} /\left[1+e^{f(x)}\right]$ and the probability that migrants did not realize an expected better life due to rural-urban migration is $1-P_{i}$. By logarithmic conversion, we can obtain $\ln \left(\frac{P_{\hat{i}}}{1-P_{\hat{i}}}\right)=f(x)$. The specific model is as follows:

$$
P_{i}=\mathrm{F}\left(a+P_{i}\right)=F\left(\alpha+\sum_{j=1}^{m} \beta_{j} x_{i j}\right)=\frac{1}{\left(-\alpha+\sum_{j=1}^{m} \beta_{j} x_{i j}\right.}
$$

where $P_{i}$ is the probability that the ith migrant realized his expected better life due to rural-urban migration; $\boldsymbol{\beta}_{j}$ is the regression coefficient of the jth influencing factor; $\mathrm{m}$ is the number of influencing factors; $x_{i j}$ is independent variable, indicating the jth influencing factor of ith migrant; $\alpha$ is regression intercept.

The primary outcome variable in the study is the realization of a better life desired by migrants because of rural-urban migration. In the logistic model, the independent variables include the occupation of respondents, income, access to health services, the urban environment to which they migrated, the destination's law and order situation, and the attitudes of neighbors towards migrants.

The dichotomous logistic regression model was conducted using SPSS 20.0 software to assess the significant factors responsible for achieving a better life predicted in the destination. With the study of logistic regression, the significantly contributing factors for realizing the anticipated better life of migrants were identified and are presented in Table 6 . The findings suggested that, contrary to no fixed job, service as an occupation significantly contributed to achieving the expected better life of migrants $(\mathrm{OR}=1.04)$, monthly income of BDT 15000 or more contributed significantly more to realizing the expected better life of migrants compared to monthly income of less than BDT 5000 ( $\mathrm{OR}=2.85$ for BDT $15001 \sim 30000$, and $\mathrm{OR}=4.90$ for more than BDT 30000). In comparison to no access to reliable doctors or hospitals, easy access to reliable doctors $(\mathrm{OR}=3.93)$ significantly contributed to the realization of the predicted better lives of migrants. Supportive neighbors $(\mathrm{OR}=4.31)$, neighbors with good social responsibilities $(\mathrm{OR}=5.11)$ and conscientious neighbors $(\mathrm{OR}=4.69)$ have contributed significantly to the realization of the dream of a better life for migrants.

\section{CONCLUSIONS}

Equivalent work opportunities vary between rural and urban areas. Discrepancies in total-factor productivity are responsible for differences between countries in equal employment opportunities and per capita income. Ruralurban migration results from disparities between regions in equal employment opportunities and per capita income, thereby migrate people from less-developed rural areas to more developed urban areas. They move to look for 
perceived or actual jobs, residential, health, and education opportunities. Each migrant leaves his or her place of origin in search of a better life in destination places.

Table-6. Ordinal logistic regression analysis of factors influencing realization of expectation of better life.

\begin{tabular}{|c|c|c|c|}
\hline Factors & Coefficient & $\mathrm{SE}$ & $\mathbf{O R}$ \\
\hline \multicolumn{4}{|c|}{ Occupation } \\
\hline No fixed job (ref.) & - & - & 1.0 \\
\hline Day labor & -0.32 & 0.89 & 0.72 \\
\hline Business & -0.44 & 0.81 & 0.64 \\
\hline Service & $0.04^{*}$ & 0.35 & 1.04 \\
\hline \multicolumn{4}{|c|}{ Income } \\
\hline$<$ BDT 5000 (ref.) & - & - & 1.0 \\
\hline BDT $5000 \sim 15000$ & -.21 & 0.50 & 0.81 \\
\hline BDT $15001 \sim 30000$ & $1.05 *$ & 0.80 & 2.85 \\
\hline$>$ BDT 30000 & $1.59^{*}$ & 0.80 & 4.90 \\
\hline \multicolumn{4}{|c|}{ Health facilities } \\
\hline No reliable doctor/hospital (ref.) & - & - & 1.0 \\
\hline Easy access to specialized doctors & $1.36^{*}$ & 0.91 & 3.93 \\
\hline Easy access to specialized hospital & 0.76 & 0.71 & 2.14 \\
\hline \multicolumn{4}{|c|}{ Attitude of neighbor } \\
\hline Unpleasant neighbor(ref.) & - & - & 1.0 \\
\hline Supportive neighbor & $1.46^{*}$ & 0.84 & 4.31 \\
\hline Having strong social commitment & $1.63 *$ & 0.81 & 5.11 \\
\hline Disciplined family & $1.54^{*}$ & 0.78 & 4.69 \\
\hline \multicolumn{4}{|c|}{ Law and order situation } \\
\hline Vulnerable (ref.) & - & - & 1.0 \\
\hline Neutral & -0.13 & 0.73 & 0.87 \\
\hline Supportive & 1.18 & 0.68 & 3.09 \\
\hline \multicolumn{4}{|c|}{ Environment of the urban } \\
\hline Terrorism free (ref.) & - & - & 1.00 \\
\hline Without traffic jam & 0.36 & 0.98 & 1.43 \\
\hline Pollution free & -0.70 & 0.72 & 0.49 \\
\hline Neat and clean & 0.41 & 0.78 & 1.51 \\
\hline Constant & 2.69 & 1.22 & 14.78 \\
\hline
\end{tabular}

Note: *Significant at $5 \%$ level of significance, $\mathrm{SE}=$ Standard Error, OR= Odds Ratio.

But for many reasons every migrant is unable to realize an anticipated better life. Results of the study showed that the dominant factors of migration were the pull factors which indicated that perceived or real income generation and other basic opportunities were more attractive in the destination places than in the origin places. Nearly all the migrants changed their places of living in search of a better life and nearly ninety percent could realize a better life expected. The realization of an expected better life was associated with some important factors such as income at the destination locations, profession, migrants' educational qualification, accessibility to health care facilities, transportation system and housing condition at the destination location. The statistical analysis showed that the sensing of an anticipated better life was more in migrants engaged in service, belonged to the highincome community (more than BDT 15000 per month), easy access to specialist physicians / hospitals, and lived with friendly, highly socially committed and disciplined neighbors. To grow a country more prosperously, it is important to develop rural areas alongside urban areas. Even in places of origin, a migrant can fulfill his / her expected better life if approximately equal opportunities in places of origin and destination can be assured. The government should therefore boost educational facilities, work prospects, easy access to better health care facilities in rural areas, and finally encourage measures for equivalence between urban and rural areas. Well-managed migration will help optimize the realization of a better life expectancy and reduce migration-related risks. Expected migrants from rural to urban areas should analyze current socio-economic conditions, social networks in place of destination prior to migration and their characteristics, in particular age, ability and education. A favorable combination of these supporting components may help migrants achieve their ultimate objective of a better life. 
Funding: This study received no specific financial support.

Competing Interests: The authors declare that they have no competing interests.

Acknowledgement: All authors contributed equally to the conception and design of the study.

\section{REFERENCES}

Acharya, C. P., \& Leon-Gonzalez, R. (2014). How do migration and remittances affect human capital investment? The Effects of Relaxing Information and Liquidity Constraints. Journal of Development Studies, 50(3), 444-460. Available at: https://doi.org/10.1080/00220388.2013.866224.

Adams, A. M., Islam, R., \& Ahmed, T. (2015). Who serves the urban poor? A geospatial and descriptive analysis of health services in slum settlements I Dhaka, Bangladesh. Health Policy and Planning, 30(suppl 1), i32-i45. Available at: https://doi.10.1093/heapol/czu094.

Adams, R. H. (2006). Remittance and poverty in Ghana. Working Paper 3838, World Bank Policy Research.

Akther, S., \& Bauer, S. (2014). Household level determinants of rural-urban migration in Bangladesh. International Journal of Social, Behavioral, Educational, Economic, Business and Industrial Engineering, 8(1), 24-27. Available at: http://scholar.waset.org/1999.10/9997037.

Amare, M., Hohfeld, L., Jitsuchon, S., \& Waibel, H. (2012). Rural-urban migration and employment quality: A case study from Thailand. Asian Development Bank Economics Working Paper Series No. 309.

Biswas, R. K., Kabir, E., \& Khan, T. A. (2019). Causes of urban migration in bangladesh: evidence from the urban health survey. Population Research and Policy Review, 38, 593-614. Available at: https://doi.org/10.1007/s11113-019-09532-3.

Bryan, G., \& Morten, M. (2015). Economic development and the spatial allocation of labor: Evidence from Indonesia. Unpublished Working Paper, Stanford University.

Gollin, D., Lagkos, D., \& Waugh, M. E. (2014). The agricultural productivity gap. Quarterly Journal of Economics, 129(2), 939993. Available at: https://doi.org/10.1093/qje/qjto56.

Guest, P. (2003). Bridging the gap: Internal migration in Asia. Paper presented at the Paper presented at the Conference on African Migration in Comparative Perspective; Johannesburg, South Africa. Jun. 2003.

Hakim, A. A., \& Boz, I. (2019). Influencing factors of rural families' migration to urban area: The Case of Kabul, Afghanistan. Asian Journal of Agricultural Extension, Economics \& $\quad$ Sociology, 37(4), 1-10. Available at: https://doi.10.9734/AJAEES/2019/v37i430286.

Hsieh, C. T., \& Klenow, P. J. (2009). Misallocation and manufacturing TFP in China and India. Quarterly Journal of Economics, 124, 1403-1448. Available at: https://doi.org/10.1162/qjec.2009.124.4.1403.

Istiaque, A., \& Mahmud, M. S. (2011). Migration objectives and their fulfillment: A micro study of the rural-urban migrants of the slums of Dhaka city. Geografia Malaysian Journal of Society and Space, 7(4), 24-29. Available at: https://www.researchgate.net/publication/220048815.

Katewongsa, P. (2015). Benefits of rural-urban migration for migrants' better life: A case study in Nang Rong, Buriram Province, Thailand. Thammasat Review 18(1), 63-81. Available at: https:// www.researchgate.net/publication/289519622.

Ma, L., Chen, M., Che, X., \& Fang, F. (2019). Farmers' rural-to-urban migration, influencing factors and development framework: A case study of Sihe Village of Gansu, China. International Journal of Environmental Research and Public Health, 16(5), 1-19. Available at: 10.3390/ijerph 16050877.

Madu, I. A. (2006). Spatial inequality in Nigeria: The imperative of geographic perspectives in the development process. Journal of Social and Economic Development, 8(2), 105-120. Available at: http://www.isec.ac.in/JSED_v8_i2_105-120.pdf.

McMillan, M. S., \& Rodrik, D. (2011). Globalization, structural change and productivity growth. NBER Working Paper No. 17143 .

Meyer, D., \& Shera, A. (2017). The impact of remittances on economic growth: An econometric model. Economic, 18(2), 47-155. Available at: https://doi.org/10.1016/j.econ.2016.06.001. 
Mulubrhan, A., Lena, H., \& Hermann, W. (2011). Finding quality employment through rural urban migration: A case study from Thailand. Paper presented at the Proceedings of the German Development Economics Conference, Berlin 2011, No. 4, ZBW - Deutsche Zentralbibliothek für Wirtschaftswissenschaften, Leibniz-Informationszentrum Wirtschaft, Kiel und Hamburg.

Nahar, M. A. (2020). Gravity of rural-urban migration and its impact on Bangladesh. The Financial Express, 20(48), 01-01.

Nauman, E., Van Landingham, M., Anglewicz, P., Patthavanit, \& Punpuing, S. (2015). Rural-to-urban migration and changes in health among young adults in Thailand. Demography, 52(1), 233-257. Available at: https://doi:10.1007/s13524-0140365-y.

Nguyen, D. L., Grote, U., \& Nguyen, T. T. (2017). Migration and rural household expenditures: A case study from Vietnam. Economic Analysis and Policy, 56, 163-175. Available at: https://doi.org/10.1016/j.eap.2017.09.001.

Nguyen, D. L., Grote, U., \& Nguyen, T. T. (2019). Migration, crop production and non-farm labor diversification in rural Vietnam. Economic Analysis and Policy, 63, 175-187. Available at: https://doi.org/10.1016/j.eap.2019.06.003.

Niva, V., Taka, M., \& Varis, O. (2019). Rural-urban migration and the growth of Informal settlements: A socio-ecological system conceptualization with insights through a "Water Lens. Sustainability, 11, 1-16. Available at: https://doi:10.3390/su11123487.

Phan, D., \& Coxhead, I. (2019). Rural-urban migration and remittances in vietnam: Evidence from migrant tracer data. In: Liu A., Meng $X$. (eds) Rural-urban migration in Vietnam. Population economics. Cham: Springer.

Rashid, M. M. (2013). Rural-urban female migration in Bangladesh: Need for information support and institutional responses.

Global Journal of Human Social Science Sociology \& Culture, 13(5), 1-10. Available at: https://https://socialscienceresearch.org/index.php/GJHSS/article/view/779/726.

Rempel, H., \& Lobdell, R. A. (2007). The role of urban-to-rural remittances in rural development. The Journal of Development Studies, 14(3), 324-334. Available at: https://doi:10.1080/00220387808421678.

Restuccia, D., \& Rogerson, R. (2008). Policy distortions and aggregate productivity with heterogeneous establishments. Revierw of Economic Dynamics, 11(4), 707-720. Available at: https://doi.org/10.1016/j.red.2008.05.002.

Restuccia, D., Yang, D. T., \& Zhu, X. (2008). Agriculture and aggregate productivity: A quantitative cross-country analysis. Journal of Monetary Economics, 55, 234-250. Available at: https://doi.org/10.1016/j.jmoneco.2007.11.006.

Sjaastad, L. A. (1962). The costs and returns of human migration. Journal of Political Economy, 70(5), 80 - 93. Available at: https://doi.org/10.1086/258726.

Stratana, A., \& Chistrugaa, M. (2012). Economic consequences of remittances. Case of Moldova. Procedia Economics and Finance, 3, 1191-1 195. Available at: https://doi:10.1016/S2212-5671(12)00295-X.

Todaro, M. P., \& Maruszko, L. (1987). Illegal migration and us immigration reform: A conceptual framework. Population and Development Review, 13(1), 101-114. Available at: https://doi:10.2307/1972122.

Uddin, M. N., \& Firoj, M. (2013). Causes and consequences of rural-urban migration in Bangladesh: An empirical study in Chittagong City. International Journal of Ethics in Social Sciences, 1(1), 89-104.

Vollrath, D. (2009). How important are dual economy effects for aggregate productivity? Journal of Development Economics, 88(2), 325-334. Available at: https://doi.org/10.1016/j.jdeveco.2008.03.004.

Wang, S. X., \& Fu, Y. B. (2019). Labor mobility barriers and rural-urban migration in transitional China. China Economic Revierw, 53, 21 1-224. Available at: https://doi.org/10.1016/j.chieco.2018.09.006.

World Bank. (2007). World bank indicators online. Washington, DC, USA: World Bank.

Young, A. (2013). Inequality, the urban-rural gap, and migration. The Quarterly Journal of Economics, 128 (4), $1727-1785$. Available at: https://doi.org/10.1093/qje/qjto25.

Views and opinions expressed in this article are the views and opinions of the author(s), International Journal of Asian Social Science shall not be responsible or answerable for any loss, damage or liability etc. caused in relation to/arising out of the use of the content. 